\title{
Influence of milk pretreatment on production of free fatty acids and volatile compounds in hard cheeses: Heat treatment and mechanical agitation
}

\author{
M. A. Vélez, M. C. Perotti, ${ }^{1}$ I. V. Wolf, E. R. Hynes, and C. A. Zalazar \\ Instituto de Lactología Industrial (INLAIN-UNL/CONICET), 1ro de Mayo 3250, Santa Fe CP 3000, Argentina
}

\begin{abstract}
This work aimed to identify technological steps that can increase fat hydrolysis and volatile compounds production in hard cheeses; these biochemical events have been related with improved piquant taste and development of genuine flavor during cheese ripening. For that purpose, 2 different pretreatments of cheese milk were tested: heat treatment and mechanical agitation. Both factors were assayed at 2 levels: milk was either batch pasteurized or nonthermally treated, and mechanical agitation was either applied or not applied. For all combinations, hard cheeses (Reggianito type) were produced in a pilot plant and ripened for $90 \mathrm{~d}$. In all cheeses the degree of lipolysis, assessed by gas chromatography, increased similarly during ripening. However, the proportion of short-chain fatty acids was higher in the cheeses made with unpasteurized milk, suggesting a higher activity of lipases with positional specificity toward the sn-3 position of the triglyceride, among which milk lipoprotein lipase is found. Similar results were found for most of the volatile compounds, determined by solid-phase microextraction-gas chromatography flame-ionization detector/mass spectrometry, which constitute the groups of ketones, alcohols, esters, and the group of acids. On the contrary, no effect of mechanical agitation was observed, although some interactions between factors were found. In the conditions of the study, results suggest that heat treatment had a higher effect on cheese lipolysis and volatile compounds production than partial destabilization of the fat emulsion produced by the agitation method applied.
\end{abstract}

Key words: milk pretreatment, cheese ripening, lipolysis, volatile compound

\section{INTRODUCTION}

During cheese ripening, a large number of flavor compounds appear as a result of a complex biochemical

Received April 19, 2010

Accepted July 2, 2010.

${ }^{1}$ Corresponding author: cperotti@fiq.unl.edu.ar process, which includes both proteolytic and lipolytic degradation of milk constituents (Le Quéré and Molimard, 2003). Lipolysis is a particularly important pathway in some varieties of cheeses. In hard-cooked cheeses, such as Reggianito, moderated lipolysis is desirable because it imparts a characteristic flavor to the product. Reggianito is an Argentinean traditional cheese that was introduced by Italian immigrants in the 19th century. It was inspired by Italian hard cheeses, but the cheese-making technique was modified and adapted to available raw materials and environmental conditions to give a distinctive product (Zannoni et al., 1984; Candioti et al., 2002). Reggianito cheese is usually made with pasteurized milk using natural whey starters. More recently, starters of Lactobacillus helveticus, both lyophilized and frozen, became commercially available; they are usually combined with organic acids or acidogens because some acidification of cheese milk is required before coagulation. Chymosin is used as a milk clotting enzyme, although some dairy plants still use adult bovine rennet; milk clotting enzymes formulations for Reggianito cheese do not include lipolytic enzymes. The cooking step is performed at somewhat lower temperature $\left(\approx 52^{\circ} \mathrm{C}\right)$ than in Italian hard-cooked cheeses, and cheeses are much smaller than Parmigiano Reggiano and Grana Padano. Their usual weight is around $5 \mathrm{~kg}$.

Free fatty acids may contribute to flavor by themselves, especially short- and intermediate-chain FFA; in addition, they also act as precursors for further reactions, which produce volatile compounds that play an important role in cheese aroma. The amount of FFA accumulated during ripening is considered to be an overall measure of lipolysis and is quite variable depending on the type of cheese, lactic and secondary starters, rennet type used, ripening time, and manufacturing technology, among other factors (McSweeney and Sousa, 2000; Collins et al., 2003).

The origins of enzymes responsible for lipolysis in cheese include the indigenous milk lipase (lipoprotein lipase; LPL), rennet preparation (rennet paste), and microbes that develop during cheese ripening either intentionally (starter bacteria and specific molds or yeasts) or unintentionally (nonstarter acid bacteria and 
adventitious molds or yeasts that should not be present at significant numbers; Collins et al., 2003). The activity of the lipolytic enzymes and the physicochemical state of fat fraction in the cheese matrix is primarily responsible for the extent of lipolysis (Collins et al., 2003).

Milk fat is in the form of globules, ranging from 0.1 to $10 \mu \mathrm{m}$ in diameter, surrounded by a thin layer of surface-active material called the milk fat globule membrane (MFGM). Therefore, this membrane acts as a natural barrier isolating the enzymes from its substrate. However, if this membrane is damaged by physical treatments (e.g., homogenization, agitation, foaming, freezing), significant lipolysis may occur (Evers, 2004a). The homogenization of milk for Danablu cheese is an example in which lipolysis is improved by modifying the integrity of MFGM (Werner et al., 1993). In particular, the effect of agitation (stirring or pumping) is dependent on other factors such as temperature, the presence of air, and the fat content. The stability of the globules decreases with the presence of air bubbles, causing disruption of them. In addition, at temperatures below $40^{\circ} \mathrm{C}$, fat begins to crystallize and the crystals can cause local structural changes to the membrane. Therefore, mechanical treatments can bring the enzymes into contact with the fat globule core fat.

On the other hand, heat treatment applied to cheese milk dramatically modifies the microbiota, denatures enzymes and serum proteins, and modifies renneting properties of milk, affecting cheese quality (Lawrence et al., 1993). Several works have studied the influence of heat treatment on lipolysis and volatile compounds in different cheese varieties. It was demonstrated that the levels of FFA in raw milk cheeses were reduced by heat treatment applied at different conditions of temperature and time (Buchin et al., 1998; Pinna et al., 1999; Shakeel-Ur-Rehman et al., 2000; Barron et al., 2007; Hickey et al., 2007; Atasoy and Türkoğlu, 2009).

As for volatile compounds, pasteurization generally reduces levels of volatile compounds, such as alcohols, aldehydes and ketones, esters, and fatty acids (Skeie and Ardö, 2000; Ortigosa et al., 2001). However, higher levels of ketones, particularly methyl-ketones, have been found in cheeses made with pasteurized milk (Barron et al., 2007)

This work was aimed to identify technological steps that can increase fat hydrolysis and volatile compounds production in hard cheeses, with a view to potential applications such as accelerating cheese ripening or intensifying cheese piquant taste. We tried 2 different approaches: to improve the access of lipases and esterases to triglycerides and to avoid the thermal denaturation of enzymes by applying different pretreatments to cheese milk.

\section{MATERIALS AND METHODS}

\section{Experimental Design}

The influence of 2 different factors on lipolysis and production of volatile compounds was assessed: heat treatment of the milk and mechanical agitation of cream, before standardizing fat content in the cheese-making milk. Both factors were studied at 2 levels, totaling 4 treatments: cheeses made with pasteurized milk and nonagitated cream (control; PN), cheeses made with pasteurized milk and cream treated by agitation (PA), cheeses made with unpasteurized milk and nonagitated cream (UN), and cheeses made with unpasteurized milk and treated cream (UA). Four replicate cheesemakings were performed on different days with different milk.

\section{Pretreatment of Cheese Milk}

Raw bulk milk [40 L; pH $6.60 \pm 0.05$; acidity $18 \pm$ $1^{\circ} \mathrm{D}(1 \mathrm{D}=100 \mathrm{mg} / \mathrm{L}$ of lactic acid)] was supplied by a nearby dairy plant. A volume of milk was centrifuged $(500 \times g$, Alfa Laval, Lund, Sweden) at a flow of 40 $\mathrm{L} / \mathrm{h}$ and at $40^{\circ} \mathrm{C}$, and skim milk ( $<0.5 \%$ of fat content) and cream (approximately $50 \%$ of fat content) were obtained. These fractions were mixed to obtain a milkmilk fat substrate with $30 \%$ fat, which was treated by agitation to induce controlled damage to the fat globule membrane in order to improve the accessibility of lipases to triglycerides. For that purpose, the mix of milk-milk fat was cooled at $5^{\circ} \mathrm{C}$ and agitated mechanically in an industrial blender (Metvisa, Santa Catarina, Brazil) at $2,800 \mathrm{rpm}$ for $2 \mathrm{~min}$. Samples treated in this way were labeled as agitated, and untreated samples (controls) were included and labeled as nonagitated.

Cheese milk was obtained by diluting the milk-milk fat substrate to $3 \%$ fat with skim milk. The skim milk was obtained from either centrifugal separation or "natural creaming" for $12 \mathrm{~h}$. The first was used to manufacture cheeses with pasteurized milk. Natural creaming was employed for the cheeses with unpasteurized milk to reduce microbial load without applying thermal treatment.

The procedure was similar to that used in Italian cheeses, like Parmigiano Reggiano and Grana Padano, in which milk is partially skimmed for about 8 to $12 \mathrm{~h}$. Milk is left in shallow separation basins overnight and the fat that rises naturally to the surface is creamed off. The skim milk is collected from the bottom of the basins. During this process, the microbial content of the milk is reduced (Battistotti and Corradini, 1993).

\section{Cheese-Making Trials}

The standard process of Reggianito cheese-making was adapted to laboratory scale and applied to obtain 
miniature hard-cooked cheeses in a clean but not aseptic environment (Hynes et al., 2004). Four vats (5 L capacity) were operated simultaneously; 1 cheese of about $0.5 \mathrm{~kg}$ was obtained from each vat.

In the first and second treatments (PN and PA cheeses), milk was pasteurized by heating at $65^{\circ} \mathrm{C}$ for $20 \mathrm{~min}$ in the vats and then cooled to $33^{\circ} \mathrm{C}$. In the third and fourth treatments (UN and UA cheeses), the milk was not pasteurized but rather was heated to $33^{\circ} \mathrm{C}$. After that, $\mathrm{CaCl}_{2}$ (Merck, Darmstadt, Germany) was added at a final concentration of $0.014 \%$ to milk. Milk pH was adjusted to the target value for Reggianito cheeses (6.30) with lactic acid (1.5\%); after that a mixed commercial starter of Lactobacillus helveticus and Lactobacillus bulgaricus (Chr. Hansen Argentina, Quilmes, Argentina) was added in a concentration of $106 \mathrm{cfu} /$ $\mathrm{mL}$ of milk. After manual stirring, $70 \mathrm{mg}$ of chymosin (Maxiren 150, Gist, Boulogne-Billancourt, France) previously dissolved in $10 \mathrm{~mL}$ of distilled water was added. Coagulum formation and strengthening took 18 to 20 min, after which curd was cut to the appropriate grain size and the mixture of the curds and whey was stirred and heated at $0.5^{\circ} \mathrm{C} / \mathrm{min}$ until it reached $44^{\circ} \mathrm{C}$ to reduce moisture in the curd grains. After that, the mixture was more rapidly heated to $52^{\circ} \mathrm{C}\left(1^{\circ} \mathrm{C} / \mathrm{min}\right)$ and stirring was stopped. The curds were separated from the whey and placed in molds, pressed for $20 \mathrm{~h}$, and brined for 12 $\mathrm{h}$ in saturated brine at $12^{\circ} \mathrm{C}$. Cheeses were ripened $90 \mathrm{~d}$ at $85 \%$ relative humidity and $12^{\circ} \mathrm{C}$; after the first $2 \mathrm{wk}$ they were wrapped in plastic film to avoid overdrying. Samples were taken on $\mathrm{d} 3$ and 90 according to IDF standard method 50C (IDF, 1995) and were stored at $-18^{\circ} \mathrm{C}$ until analysis.

\section{Free and Total Fat Analysis}

Free fat was assessed in the agitated and nonagitated milk-milk fat substrates and in the whey obtained from cheese-makings by centrifugation. Centrifugal separation makes use of a difference of density between fat that has escaped from the fat globule and fat that is still surrounded by the native membrane (Evers, 2004b).

Before sampling, the substrates were warmed in a bath at $40^{\circ} \mathrm{C}$ for $15 \mathrm{~min}$ and thoroughly homogenized by repeated inversion of the containers. Then, $40 \mathrm{~mL}$ was weighted in $50 \mathrm{~mL}$-tubes and maintained at $60^{\circ} \mathrm{C}$ for $15 \mathrm{~min}$, then centrifuged at $600 \times g$ for $10 \mathrm{~min}$ and placed again in the bath at $60^{\circ} \mathrm{C}$ for 5 min (Evers, 2004b). Finally, the height of the free fat layer was measured with a caliper. Total fat in whey was analyzed by IDF method 22A (IDF, 1983).

\section{Global Composition of Cheeses and Microbial Counts}

Cheese samples were analyzed at the beginning $(3 \mathrm{~d})$ and at the end $(90 \mathrm{~d})$ of ripening for $\mathrm{pH}$ by the American Public Health Association method (Bradley et al., 1992), DM by oven drying to a constant weight at 102 $\pm 1^{\circ} \mathrm{C}$ by IDF standard $4 \mathrm{~A}$ (IDF, 1982), fat according to Gerber-Van Gulik ISO method 3433 (ISO, 1975), and protein content by Kjeldahl method (IDF, 1993). All analyses were performed in duplicate.

Total thermophilic lactic flora at 0 (fresh curd), 3 , and $90 \mathrm{~d}$ of ripening was determined by plating sample dilution on skim milk agar and counting plate colonies after $48 \mathrm{~h}$ of incubation at $37^{\circ} \mathrm{C}$ (Candioti et al., 2002). Coliforms were enumerated on Bile Red Violet agar and the plates were incubated for $24 \mathrm{~h}$ at $30^{\circ} \mathrm{C}$ (Christen et al., 1992).

\section{FFA Analysis by GC-Flame lonization Detector}

Extraction of cheese lipids, isolation of FFA, and derivatization to ethyl esters were performed in duplicate as described by Perotti et al. (2005) with minor modifications. Fatty acids ethyl esters were analyzed using a PerkinElmer model GC-9000 series gas chromatograph (PerkinElmer Corp., Waltham, MA) equipped with a flame ionization detector (FID) and with a split/splitless injector. Free fatty acids were separated on a fused silica capillary column $(60 \mathrm{~m} \times 0.25 \mathrm{~mm}$; PE-Wax, PerkinElmer Corp.) coated with a bonded polyethylene glycol stationary phase $(0.25 \mu \mathrm{m}$ layer thickness $)$. Gaschromatographic parameters were as follows: carrier gas $\mathrm{N}$ flow at $2 \mathrm{~mL} / \mathrm{min}$; injected amount at $1 \mu \mathrm{L}$; split mode injection at 1:50 splitting ratio; injector and detector temperatures at 250 and $300^{\circ} \mathrm{C}$, respectively; oven temperatures running from $75^{\circ} \mathrm{C}(1.5 \mathrm{~min})$ up to $150^{\circ} \mathrm{C}$ $(10 \mathrm{~min})$ at $8^{\circ} \mathrm{C} / \mathrm{min}$, then increased to a final temperature of $230^{\circ} \mathrm{C}(15 \mathrm{~min})$ at $10^{\circ} \mathrm{C} / \mathrm{min}$. The quantification $\left(\mathrm{C}_{4: 0}-\mathrm{C}_{18: 2}\right)$ was performed using the internal standard method, with enantic $\left(\mathrm{C}_{7: 0}\right)$ and margaric $\left(\mathrm{C}_{17: 0}\right)$ acids (Sigma-Aldrich, St. Louis, MO) as internal standards added to the cheese sample at the extraction step.

The FID outsignal was recorded and the chromatograms were processed using Turbochrom software (version 4, Perkin Elmer Corp.). The concentrations were expressed as milligrams of FFA per $100 \mathrm{~g}$ of fat.

\section{Volatile Compounds by GC-FID/MS}

A manual solid-phase microextraction (SPME) device equipped with a Stable-Flex divinylbenzene/car- 
boxen/polydimethylsiloxane $(1 \mathrm{~cm} \times 50 / 30 \mu \mathrm{m}$; Supelco, Bellafonte, PA) was used to isolate and concentrate the volatile compounds. Five grams of grated cheese was weighed in a $30-\mathrm{mL}$ glass vial and hermetically sealed with an aluminum seal and butyl-Teflon septa. The vials were maintained at $40 \pm 1^{\circ} \mathrm{C}$ for $10 \mathrm{~min}$ and then the fiber was exposed to the headspace for $15 \mathrm{~min}$. After exposure, the fiber was thermally desorbed into a GC and left in the injection port (equipped with an inlet liner, $0.75 \mathrm{~mm}$ i.d.) for $5 \mathrm{~min}$. The injector was set at $250^{\circ} \mathrm{C}$ and operated in the splitless mode.

The same instrument and column described in the FFA Analysis section were used to obtain information on volatile compounds peak areas (expressed as arbitrary units) and to compare the profiles of different cheeses. The oven temperature program was as follows: $45^{\circ} \mathrm{C}(4 \mathrm{~min}), 8^{\circ} \mathrm{C} / \mathrm{min}$ to $150^{\circ} \mathrm{C}(3 \mathrm{~min})$, and $10^{\circ} \mathrm{C} / \mathrm{min}$ to $250^{\circ} \mathrm{C}$ (5 min). The carrier gas $\mathrm{N}$ flow was $2 \mathrm{~mL} / \mathrm{min}$ and the detector temperature was $300^{\circ} \mathrm{C}$.

Another GC, coupled to an ion trap mass spectrometer (GC-MS Shimadzu QP-5000, Shimadzu Corp., Tokyo, Japan), was used to identify the compounds, keeping the same chromatographic conditions and with the same column as the CG-FID analysis. Mass spectra were obtained with $70 \mathrm{eV}$ electron impact ionization (electron ionization mode). The mass range used was 42 to $300 \mathrm{~m} / z$ (scan rate $250 \mathrm{amu} / \mathrm{s}$ ). The identification of volatile compounds was performed by matching mass spectra with NIST-62 library of standard compounds (National Institute of Standards and Technology, Gaithersburg, MD). Both mass spectrometric identifications and chromatographic peaks of FID were further confirmed by comparing retention times with reference standards (Sigma-Aldrich) or bibliographical data. The results were expressed as peak areas in arbitrary units. The analysis was performed in duplicate in cheeses at the end of ripening.

\section{Statistical Analysis}

The SPSS software (version 10.0, SPSS Inc., Chicago, IL) was used for the statistical analysis. Twoway ANOVA was carried out on data of compositional parameters, FFA and volatile compound profiles, using a general linear model procedure with least significant difference pairwise comparison at $95 \%$ confidence level.

\section{RESULTS AND DISCUSSION}

\section{Efficiency of Mechanical Treatment on Fat Globule Membrane Damage}

The term free fat is used to denote a particular parameter that has been claimed to correlate with the de- gree of damage to fat globules (Evers, 2004b). However, it is controversial because it is believed that free fat cannot exist in milk for more than a few fractions of a second before being covered by surface-active material present in milk plasma (Walstra et al., 1999).

In the present work, we understand by "free fat" a method-defined parameter: the fat extracted by centrifugation in the chosen and fixed conditions (Evers, $2004 b)$. Free fat was found only in milk-milk fat substrates in which stirring treatment was applied (agitated mixtures). The height of free fat layer ranged between 7.8 and $8.9 \mathrm{~mm}$ in agitated samples, whereas no free fat layer was visible in nonagitated samples. These results showed that the mechanical treatment was efficient at producing membrane damage to the globules, which could allow a greater accessibility of enzyme substrate.

As for retention of fat in curd matrix, no significant differences $(P<0.05)$ were found in the total fat content of whey samples from nonagitated and agitated cheeses, mean values being $0.45 \pm 0.03$ and $0.50 \pm$ $0.02 \%$, respectively. This observation implies that mechanical treatment did not increase fat loss in the whey. However, free fat analysis in whey samples showed some nonquantifiable differences: drops of free fat appeared in whey from agitated cheeses after centrifugation, which were not observed on the surface of whey from nonagitated cheeses.

\section{Global Composition of Cheeses and Microbial Counts}

Global composition of 3-d-old cheeses was similar to that previously reported for this type of cheese (Candioti et al., 2002). The effect of treatments on global composition was observed both at the beginning of the ripening and after $90 \mathrm{~d}$. Consequently, only 90-d-old cheeses composition is shown (Table 1). All the values were within the range established by Argentinean legislation for Reggianito cheese (ANMAT, 2009).

Moisture content of all cheeses decreased during ripening, as was expected because of water evaporation before vacuum packing. No significant differences in moisture content were found $(P>0.05)$ between UN and UA cheeses and between PN and PA cheeses, which suggests that the mechanical treatment applied to induce controlled damage in the MFGM did not cause differences in curd water retention. An opposite trend was verified when studying the heat treatment factor: cheeses made with pasteurized milk (PN and PA) had a significantly higher $(P<0.05)$ moisture content than cheeses made with unpasteurized milk (UN and UA). Severe heat treatment diminishes milk coagulation ability and salt equilibrium, which in turn can affect water retention by proteins and influence cheese moistures 
Table 1. Composition of 90-d-old cheeses and significance of the main effects and their interaction ${ }^{1}$

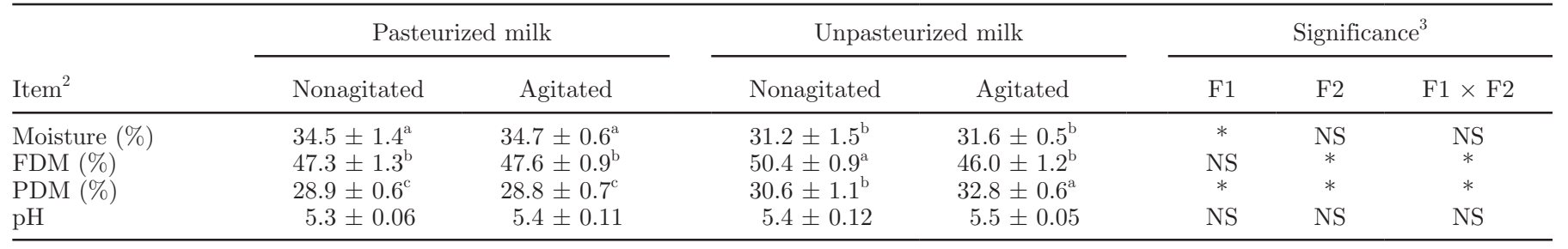

${ }^{\mathrm{a}-\mathrm{c}}$ Values within rows with different superscripts differ significantly $(P<0.05)$.

${ }^{1}$ Values are means \pm standard deviation.

${ }^{2} \mathrm{FDM}=$ fat in $\mathrm{DM}$; PDM $=$ protein in DM.

${ }^{3} \mathrm{~F} 1=$ heat treatment; $\mathrm{F} 2=$ mechanical agitation.

$* P<0.05$.

(Lawrence et al., 1993). However, low temperature batch pasteurization such as that applied in this work has not previously been related with changes in cheese composition.

The UN cheeses showed the highest values $(P<$ 0.05 ) of fat content expressed on a dry basis. The other cheeses (PA, PN, and UA) had similar values $(P>$ $0.05)$. In this sense, a significant interaction between factors was found, so the lower fat in DM percentage in $\mathrm{PA}, \mathrm{PN}$, and UA cheeses is probably attributable to a combination of heat treatment and cream agitation.

As for protein content, the results are consistent with the values of moisture and fat content: pasteurized cheeses showed lower values of protein in DM percentage than unpasteurized cheeses, and significant interaction between factors was detected. The $\mathrm{pH}$ values were similar in all cheeses $(P>0.05)$.

Total thermophilic lactic flora reached a maximum of $10^{8} \mathrm{cfu} / \mathrm{g}$ on $\mathrm{d} 3$ for all cheeses and then decreased by 1 log order during ripening. This suggested that natural creaming was acceptable to reduce initial load of total thermophilic lactic bacteria and that plate count values were mainly attributable to the starter, which reached similar values for pasteurized and unpasteurized cheeses. Coliform bacteria were $<10^{2} \mathrm{cfu} / \mathrm{g}$. No significant differences were found among cell load of cheeses from different treatments (results not shown).

\section{Lipolysis in Cheeses}

The level of lipolysis expressed total FFA ( $\mu$ mol per $100 \mathrm{~g}$ of cheese fat) increased during ripening as a consequence of the increase of each FFA assayed (results not shown). This trend has already been demonstrated for most cheese varieties; consequently, it can be assumed that both lipolytic activity and fats susceptible to enzyme action are present throughout ripening (Werner et al., 1993; O'Mahony et al., 2006; Hickey et al., 2007; Atasoy and Türkoğlu, 2009; Malacarne et al., 2009; Voigt et al., 2010).
On the other hand, no differences $(P>0.05)$ were found among cheeses from the 4 treatments applied (PN, PA, UN, and UA) for the 2 sampling times studied. Total content of FFA (global mean values) in 3- and 90-d-old cheeses was approximately 670 and $940 \mathrm{mg} / 100 \mathrm{~g}$ of cheese fat, respectively. These values were similar to those previously found for Reggianito cheese (Perotti et al., 2005). Besides, in comparison with other internal bacterially ripened varieties such as Italian cheeses, they can be considered low; they are similar to the values reported for Cheddar and Gouda cheeses (McSweeney and Sousa, 2000; Collins et al., 2003). Individual and total concentrations of FFA in 90-d-old cheeses are shown in Table 2.

No significant differences were found in the concentrations of most fatty acids between cheeses in which the integrity of the fat globule membrane had been damaged (agitated cheeses) and those in which the milk fat had not been treated (nonagitated cheeses) for the 2 methods of heat treatment assayed (unpasteurized and pasteurized). In C6:0, however, the mechanical agitation-heat treatment interaction was significant. The UN cheeses had the highest concentration of C6:0, followed by UA cheeses, which were significantly different $(P<0.05)$. Both PN and PA cheeses had the lowest concentrations of $\mathrm{C} 6: 0$; they also were significantly different from UN and UA cheeses.

Increase of $\mathrm{C} 4: 0$ and $\mathrm{C} 6: 0$ concentrations in unpasteurized cheeses could be attributed to the action of both LPL and microbial lipases; in particular, LPL shows specificity toward sn-3 position of triacylglycerides, in which short-chain fatty acids (SCFA) are predominantly esterified (Collins et al., 2003). To assess whether certain FFA were affected preferentially by the factors studied, the proportions of the FFA groups (short-, medium-, and long-chain) were calculated. The percentages of SCFA $\left(\mathrm{C}_{4: 0}-\mathrm{C}_{8: 0}\right)$ in unpasteurized cheeses was significantly $(P<0.05)$ higher than in pasteurized cheeses (Figure 1), but no significant differences related to mechanical agitation were revealed between agitated 


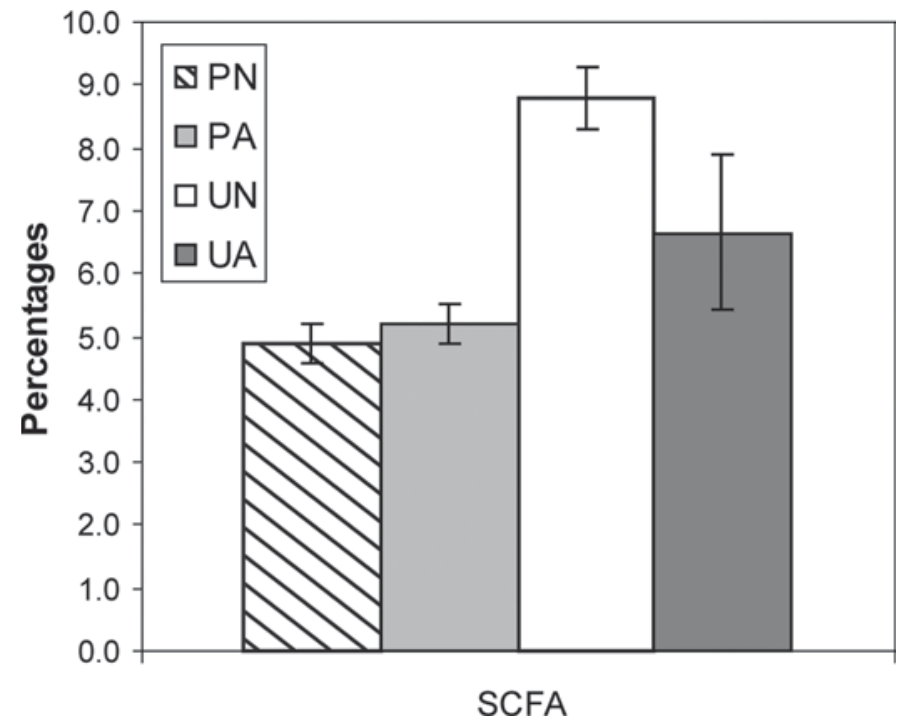

Figure 1. Proportion (\%) of short-chain fatty acids (SCFA) in 90-d-old cheeses. $\mathrm{PN}=$ cheeses made with pasteurized milk and nonagitated cream; $\mathrm{PA}=$ cheeses made with pasteurized milk and cream treated by agitation; UN $=$ cheeses made with unpasteurized milk and nonagitated cream; UA $=$ cheeses made with unpasteurized milk and treated cream.

and nonagitated cheeses. Medium-chain fatty acid $\left(\mathrm{C}_{10: 0}-\mathrm{C}_{12: 0}\right)$ percentages were quite similar among all cheeses; 2-way ANOVA analysis showed no significant differences between treatments. For long-chain fatty acids $\left(\mathrm{C}_{14: 0}-\mathrm{C}_{18: 2}\right)$, the values increased when heat was applied $(P<0.05)$, and the agitation method had no influence in this group.

In pasteurized milk cheeses, lipolysis can be attributed mainly to the action of microbial lipases and esterases, which, because of the diversity of their origin, may show a broader specificity (McSweeney and
Sousa, 2000; Collins et al., 2003), and indigenous LPL would contribute to a lesser extent because it is almost completely inactivated by pasteurization (Collins et al., 2003).

Several studies found that pasteurization has a negative influence not only on the level of lipolysis reached during ripening but also on the proportions of FFA groups. Shakeel-Ur-Rehman et al. (2000) reported that lipolysis was considerably higher in Cheddar cheeses made from raw milk and in cheeses made from pasteurized milk to which a percentage of raw milk had been added than in cheeses made from pasteurized milk. Hence, it was suggested that LPL and lipases of indigenous nonstarter acid bacteria may have contributed to a higher level of FFA. Pinna et al. (1999) evaluated the extent of lipolysis in Fiore Sardo cheese made with raw and thermized milk. The thermal treatment led to a diminution of SCFA, which was attributed to the action of native milk lipases.

\section{Volatile Compounds}

A total of 36 volatile compounds were identified by SPME/MS/FID: 7 ketones, 12 alcohols, 4 esters, 3 aldehydes, 7 acids, 1 terpene, and 2 aromatic hydrocarbons (Table 3). Most of these compounds can derive from more than one metabolic pathway; precursors may be AA derived from proteolysis as well as fatty acids from lipolysis or carbohydrates (lactose, citrate, and lactate; McSweeney and Sousa, 2000; Collins et al., 2003; Le Quéré and Molimard, 2003). Almost all compounds were found in all cheeses.

For most of compounds (26) no significant interaction between the 2 principal factors studied was detected. Two-way ANOVA analysis revealed that heat

Table 2. Concentrations ( $\mu \mathrm{mol} / 100 \mathrm{~g}$ of fat) of FFA in $90-\mathrm{d}$-old cheeses and significance of the main effects and their interaction ${ }^{1}$

\begin{tabular}{|c|c|c|c|c|c|c|c|}
\hline \multirow[b]{2}{*}{ FFA } & \multicolumn{2}{|c|}{ Pasteurized milk } & \multicolumn{2}{|c|}{ Unpasteurized milk } & \multicolumn{3}{|c|}{ Significance $^{2}$} \\
\hline & Nonagitated & Agitated & Nonagitated & Agitated & $\mathrm{F} 1$ & $\mathrm{~F} 2$ & $\mathrm{~F} 1 \times \mathrm{F} 2$ \\
\hline $\mathrm{C}_{6: 0}$ & $155 \pm 25^{\mathrm{c}}$ & $162 \pm 5^{\mathrm{c}}$ & $278 \pm 1^{\mathrm{a}}$ & $199 \pm 31^{\mathrm{b}}$ & $*$ & NS & $*$ \\
\hline $\mathrm{C}_{8: 0}$ & $83 \pm 11$ & $93 \pm 22$ & $117 \pm 6$ & $89 \pm 1$ & NS & NS & NS \\
\hline $\mathrm{C}_{10: 0}$ & $124 \pm 22$ & $138 \pm 47$ & $164 \pm 12$ & $139 \pm 10$ & NS & NS & NS \\
\hline $\mathrm{C}_{12 \cdot 0}$ & $136 \pm 20$ & $152 \pm 53$ & $144 \pm 7$ & $128 \pm 7$ & NS & NS & NS \\
\hline $\mathrm{C}_{18: 0}$ & $324 \pm 28$ & $357 \pm 30$ & $328 \pm 67$ & $333 \pm 41$ & NS & NS & NS \\
\hline $\mathrm{C}_{18: 1}$ & $1,068 \pm 28$ & $1,070 \pm 87$ & $925 \pm 128$ & $941 \pm 32$ & NS & NS & NS \\
\hline $\mathrm{C}_{18: 2}^{10: 1}$ & $230 \pm 6^{\mathrm{a}}$ & $238 \pm 20^{\mathrm{a}}$ & $165 \pm 45^{\mathrm{b}}$ & $178 \pm 9^{\bar{b}}$ & $*$ & NS & NS \\
\hline Total & $3,960 \pm 196$ & $4,024 \pm 398$ & $4,048 \pm 387$ & $3,794 \pm 201$ & NS & NS & NS \\
\hline
\end{tabular}

${ }^{a-c}$ Values within rows with different superscripts differ significantly $(P<0.05)$.

${ }^{1}$ Values are means \pm standard deviation.

${ }^{2} \mathrm{~F} 1=$ heat treatment; $\mathrm{F} 2=$ mechanical agitation.

$* P<0.05$. 
treatment was practically the only factor affecting the production of volatile compounds. In this sense, the absence of thermal treatment had a positive effect based on the peak areas on some volatile compounds derived from fat (2-heptanone, 2-heptanol, 2-pentanol, ethyl hexanoate, ethyl butanoate, and butanoic and hexanoic acids), citrate (3-hydroxy 2-butanone, 2,3-butanediol, 2-butanone, and 2-butanol), and AA (2-methyl 1-propanol and 3-methyl 1-butanol).

Several studies have been carried out about the effect of pasteurization, together with other factors such as type of starter culture, on the volatile profile of different cheeses (Buchin et al., 1998; Ortigosa et al., 2001;
Gómez-Ruiz et al., 2002; Barron et al., 2007; Hickey et al., 2007; Bouton et al., 2009). The influence of the heat treatment on the production of volatile compounds is most likely related to the reduction of milk-derived microorganisms and the concomitant decrease in metabolic reactions in the cheeses (Buchin et al., 1998; Ortigosa et al., 2001). Even if pasteurized and unpasteurized cheeses had similar lactobacilli counts (results not shown), biodiversity in unpasteurized cheeses was most probably higher. Nevertheless, the activity of the native milk enzymes and the higher availability of precursors such as SCFFA cannot be excluded as a source of volatile compound increase in unpasteurized cheeses.

Table 3. Volatile compounds in cheeses after $90 \mathrm{~d}$ of ripening and significance of the main effects and their interaction ${ }^{1}$

\begin{tabular}{|c|c|c|c|c|c|c|c|}
\hline \multirow[b]{2}{*}{ Item } & \multicolumn{2}{|c|}{ Pasteurized milk } & \multicolumn{2}{|c|}{ Unpasteurized milk } & \multicolumn{3}{|c|}{ Significance } \\
\hline & Nonagitated & Agitated & Nonagitated & Agitated & $\mathrm{F} 1$ & $\mathrm{~F} 2$ & $\mathrm{~F} 1 \times \mathrm{F} 2$ \\
\hline \multicolumn{8}{|l|}{ Ketones } \\
\hline 2-Propanone & $178 \pm 4^{\mathrm{a}}$ & $171 \pm 1^{\mathrm{a}}$ & $71 \pm 42^{\mathrm{b}}$ & $76 \pm 35^{\mathrm{b}}$ & $*$ & NS & NS \\
\hline 2-Butanone & $50 \pm 3^{\mathrm{c}}$ & $42 \pm 0.2^{\mathrm{c}}$ & $96 \pm 15^{\mathrm{b}}$ & $139 \pm 9^{\mathrm{a}}$ & $*$ & $*$ & $*$ \\
\hline 2,3-Butanodione & $268 \pm 39$ & $397 \pm 79$ & $288 \pm 93$ & $324 \pm 67$ & NS & NS & NS \\
\hline 2-Hexanone & $30 \pm 3^{\mathrm{a}}$ & $31 \pm 1^{\mathrm{a}}$ & $14 \pm 2^{\mathrm{b}}$ & $11 \pm 1^{\mathrm{b}}$ & $*$ & NS & NS \\
\hline 2-Heptanone & $213 \pm 19^{\mathrm{b}}$ & $309 \pm 31^{\mathrm{a}}$ & $380 \pm 31^{\mathrm{a}}$ & $365 \pm 21^{\mathrm{a}}$ & $*$ & NS & $*$ \\
\hline 3-Hydroxy 2-butanone & $170 \pm 25^{\mathrm{c}}$ & $139 \pm 25^{\mathrm{c}}$ & $242 \pm 22^{\mathrm{b}}$ & $310 \pm 8^{a}$ & $*$ & NS & $*$ \\
\hline 2-Nonanone & $36 \pm 3^{\mathrm{c}}$ & $73 \pm 9^{b}$ & $127 \pm 12^{\mathrm{a}}$ & $71 \pm 9^{b}$ & $*$ & NS & $*$ \\
\hline \multicolumn{8}{|l|}{ Alcohols } \\
\hline 2-Propanol & $35 \pm 1^{b c}$ & $26 \pm 4^{\mathrm{c}}$ & $40 \pm 8^{\mathrm{ab}}$ & $50 \pm 3^{\mathrm{a}}$ & $*$ & NS & $*$ \\
\hline Ethanol & $2,209 \pm 29^{\mathrm{bd}}$ & $1,640 \pm 213^{\mathrm{cd}}$ & $4,093 \pm 393^{\mathrm{ab}}$ & $3,295 \pm 117^{\mathrm{ac}}$ & $*$ & $*$ & NS \\
\hline 2-Butanol & ND & ND & $17 \pm 1^{\mathrm{a}}$ & $29 \pm 14^{\mathrm{a}}$ & $*$ & NS & NS \\
\hline 2-Methyl 1-propanol & $18 \pm 1^{\mathrm{a}}$ & $11 \pm 2^{\mathrm{a}}$ & $43 \pm 3^{\mathrm{b}}$ & $43 \pm 22^{\mathrm{b}}$ & $*$ & NS & NS \\
\hline 2-Pentanol & $116 \pm 11^{\mathrm{b}}$ & $122 \pm 2^{\mathrm{b}}$ & $214 \pm 78^{\mathrm{a}}$ & $290 \pm 29^{\mathrm{a}}$ & $*$ & NS & NS \\
\hline 1-Butanol & ND & ND & $23 \pm 4^{\mathrm{a}}$ & $31 \pm 3^{\mathrm{a}}$ & $*$ & NS & NS \\
\hline 3-Methyl 1-butanol & $203 \pm 26^{\mathrm{b}}$ & $109 \pm 18^{\mathrm{b}}$ & $340 \pm 57^{\mathrm{a}}$ & $343 \pm 32^{\mathrm{a}}$ & $*$ & NS & NS \\
\hline 1-Pentanol & $20 \pm 2^{\mathrm{a}}$ & $16 \pm 0.8^{\mathrm{b}}$ & $14 \pm 0.6^{\mathrm{b}}$ & $15 \pm 1^{\mathrm{b}}$ & $*$ & NS & $*$ \\
\hline 2-Heptanol & $60 \pm 8^{b}$ & $57 \pm 3^{\mathrm{b}}$ & $103 \pm 6^{\mathrm{a}}$ & $123 \pm 9^{\mathrm{a}}$ & $*$ & NS & NS \\
\hline 1-Hexanol & $29 \pm 8^{\mathrm{a}}$ & $30 \pm 4^{a}$ & $12 \pm 2^{\mathrm{b}}$ & $14 \pm 1^{\mathrm{b}}$ & $*$ & NS & NS \\
\hline 2-Nonanol & ND & ND & $20 \pm 1^{\mathrm{a}}$ & $18 \pm 5^{\mathrm{a}}$ & $*$ & NS & NS \\
\hline 2,3-Butanediol & $11 \pm 1^{\mathrm{c}}$ & $7 \pm 0.2^{\mathrm{c}}$ & $153 \pm 10^{\mathrm{b}}$ & $189 \pm 14^{\mathrm{a}}$ & $*$ & NS & $*$ \\
\hline \multicolumn{8}{|l|}{ Esters } \\
\hline Ethyl acetate & $18 \pm 3$ & $24 \pm 12$ & $27 \pm 3$ & $16 \pm 0.6$ & NS & NS & NS \\
\hline Ethyl butanoate & $158 \pm 8^{\mathrm{b}}$ & $193 \pm 11^{\mathrm{b}}$ & $339 \pm 56^{\mathrm{a}}$ & $282 \pm 15^{\mathrm{a}}$ & $*$ & NS & NS \\
\hline Ethyl hexanoate & $14 \pm 0.2^{\mathrm{b}}$ & $28 \pm 4^{\mathrm{b}}$ & $396 \pm 186^{\mathrm{a}}$ & $141 \pm 11^{\mathrm{a}}$ & $*$ & NS & NS \\
\hline Isoamyl butanoate & ND & ND & $38 \pm 6^{\mathrm{a}}$ & $42 \pm 1^{\mathrm{a}}$ & $*$ & NS & NS \\
\hline \multicolumn{8}{|l|}{ Aldehydes } \\
\hline Acetaldehyde & $51 \pm 6^{\mathrm{a}}$ & $48 \pm 4^{\mathrm{a}}$ & $15 \pm 9^{\mathrm{b}}$ & $27 \pm 15^{\mathrm{b}}$ & $*$ & NS & NS \\
\hline 2-Methyl butanal & $17 \pm 2^{\mathrm{a}}$ & $13 \pm 3^{\mathrm{a}}$ & $26 \pm 5^{\mathrm{b}}$ & $27 \pm 6^{\mathrm{b}}$ & $*$ & NS & NS \\
\hline 3-Methyl butanal & $104 \pm 15$ & $79 \pm 16$ & $124 \pm 24$ & $125 \pm 29$ & NS & NS & NS \\
\hline \multicolumn{8}{|l|}{ Acids } \\
\hline Ethanoic & $699 \pm 31^{\mathrm{b}}$ & $762 \pm 21^{\mathrm{b}}$ & $1,207 \pm 41^{\mathrm{a}}$ & $1,189 \pm 11^{\mathrm{a}}$ & $*$ & NS & NS \\
\hline 2-Methyl propanoic & ND & ND & $221 \pm 6^{\mathrm{a}}$ & $201 \pm 12^{\mathrm{a}}$ & $*$ & NS & NS \\
\hline Butanoic & $1,411 \pm 19^{\mathrm{c}}$ & $2,190 \pm 8^{b}$ & $4,265 \pm 318^{\mathrm{a}}$ & $2,713 \pm 288^{\mathrm{b}}$ & $*$ & NS & $*$ \\
\hline 3-Methyl butanoic & $59 \pm 10^{\mathrm{a}}$ & $50 \pm 6^{\mathrm{a}}$ & $24 \pm 7^{\mathrm{b}}$ & $23 \pm 0.4^{\mathrm{b}}$ & $*$ & NS & NS \\
\hline Hexanoic & $751 \pm 79^{\mathrm{b}}$ & $1,125 \pm 23^{\mathrm{b}}$ & $1,955 \pm 136^{\mathrm{a}}$ & $1,132 \pm 245^{\mathrm{b}}$ & $*$ & NS & $*$ \\
\hline Octanoic & $87 \pm 9^{\mathrm{bc}}$ & $118 \pm 5^{\mathrm{c}}$ & $211 \pm 4^{\mathrm{a}}$ & $126 \pm 24^{\mathrm{b}}$ & $*$ & $*$ & $*$ \\
\hline Decanoic & ND & ND & $42 \pm 6^{\mathrm{a}}$ & $28 \pm 5^{\mathrm{a}}$ & $*$ & NS & NS \\
\hline \multicolumn{8}{|l|}{ Other compounds } \\
\hline p-Xylene & ND & ND & $40 \pm 4^{\mathrm{a}}$ & $37 \pm 9^{\mathrm{a}}$ & $*$ & NS & NS \\
\hline m-Xylene & $15 \pm 0.3^{\mathrm{b}}$ & $17 \pm 0.4^{\mathrm{b}}$ & $171 \pm 19^{\mathrm{a}}$ & $177 \pm 1^{\mathrm{a}}$ & $*$ & NS & NS \\
\hline D-Limonene & ND & ND & $17 \pm 3^{\mathrm{a}}$ & $20 \pm 0.4^{\mathrm{a}}$ & $*$ & NS & NS \\
\hline
\end{tabular}

${ }^{\mathrm{a}-\mathrm{d}}$ Values within rows with different superscripts differ significantly $(P<0.05)$.

${ }^{1}$ Peak areas in arbitrary units (values are means \pm standard deviation).

$* P<0.05$. 
Ketones, with an odd number of carbon atoms, are important compounds in some types of cheeses, especially mold-ripened cheeses, but also, in lower concentrations, in hard-cooked cheeses (Molimard and Spinnler, 1996; Le Quéré and Molimard, 2003; Qian and Reineccius, 2003). In particular, 2-heptanone and 2-nonanone, which originate from the oxidation of the FFA (octanoic and decanoic acids, respectively) by microbial metabolism (Collins et al., 2003), were determined in cheeses from all treatments but were significantly higher in unpasteurized cheeses.

In the case of the 2,3-butanodione (diacetyl), it had similar levels in all cheeses $(P>0.05)$ but its product of reduction, 3-hydroxy-2-butanone (acetoin) was greater in unpasteurized cheeses than in pasteurized cheeses. Acetoin can be reduced to 2,3-butanediol, then to 2-butanone, and finally to 2-butanol. The production of diacetyl and acetoin and reduction of the latter to 2,3-butanediol is generally attributed to lactic acid bacteria from the starter; however, subsequent reduction to 2-butanone and thence to 2-butanol is believed to come from the activity of adventitious bacteria (Ortigosa et al., 2001). In the present work, the highest levels of 2,3-butanediol, 2-butanone, and 2-butanol were found in unpasteurized cheeses. The synthesis of these compounds would be related to the action of microorganisms from raw milk, which is reduced considerably by pasteurization. These results are in agreement with previous studies (Buchin et al., 1998; Ortigosa et al., 2001).

In the group of alcohols, ethanol was the most abundant component; ethanol is a usual compound of cheese volatile fraction, which mostly derives from lactose fermentation, and has been detected at high levels in many cheese varieties (McSweeney and Sousa, 2000; Collins et al., 2003; Le Quéré and Molimard, 2003).

Alcohols with a longer carbon chain than ethanol are produced by the reduction of carbonyls; aldehydes are reduced to primary alcohols and ketones to secondary alcohols by 2 possible mechanisms: an enzymatic reduction by microorganisms such as molds or a chemical reduction through the decrease of redox potential (McSweeney and Sousa, 2000; Collins et al., 2003; Le Quéré and Molimard, 2003).

Higher contents of secondary alcohols (2-pentanol, 2-heptanol, and 2-nonanol) were found in unpasteurized cheeses, which was in agreement with the higher contents of the corresponding methyl ketones also found in them. The higher values found in unpasteurized cheeses of branched-chain alcohols, 2-methyl 1-propanol and 3-methyl 1-butanol, derived from AA catabolism, in respect to those of pasteurized cheeses, could suggest that the pasteurization decreased the concentration of most of AA in concordance with other authors (Ortigosa et al., 2001).

Esters are important contributors of cheese flavor, especially ethyl esters, because of their low perception threshold and fruity aromas. Ethyl hexanoate, ethyl butanoate, and isoamyl butanoate are related mainly to lipolysis process. Their synthesis depends on the biodisponibility of precursors (i.e., alcohols and acids; Liu et al., 2004; Holland et al., 2005). In unpasteurized cheeses, where the levels of ethanol, 3 methyl-1 butanol, and butyric and hexanoic acids were the highest, the content of the corresponding esters were the greatest.

Regarding acidic compounds recovered by SPME/ GC/FID, linear and even-numbered carbon fatty acids from $\mathrm{C} 2$ to $\mathrm{C} 10$ were more abundant in unpasteurized cheeses, according to the higher contents of these SCFA determined by lipolysis analysis. Branched-chain fatty acids (2-methyl propanoic and 3-methyl butanoic) are produced by the metabolism of AA (Urbach, 1995; Marilley and Casey, 2004). The level of 2-methyl propanoic acid was higher in unpasteurized cheeses than in pasteurized cheeses, but the contrary was observed for 3-methyl butanoic acid.

Only 3 aldehydes were identified, 2 of which were branched-chain aldehydes, 2-methyl butanal and 3-methyl butanal, produced from AA degradation both enzymatic and nonenzymatic (Urbach, 1995). As observed for most volatile compounds, these aldehydes levels were higher in unpasteurized cheeses. However, the content of acetaldehyde was higher in pasteurized cheeses than in unpasteurized cheeses. These results are similar to those obtained by Ortigosa et al. (2001) and Barron et al. (2007).

On the other hand, 2-way ANOVA analysis revealed interaction between the design factors for some compounds derived from fat, such as 2-heptanone, 2-nonanone, and butanoic, hexanoic, and octanoic acids. The areas of the peaks of these compounds were higher for PA cheeses than for PN cheeses, but a contrary trend was observed for unpasteurized cheeses, in which the greatest levels were obtained for UN cheeses. The availability of fat and derived FFA may have affected biochemical reactions for which they are main substrates.

\section{CONCLUSIONS}

From the 2 factors studied in this work, milk heat treatment and mechanical agitation of milk fat, the first showed the greatest influence on cheese lipolysis and production of volatile compounds. This effect was evidenced, in cheese from pasteurized milk, by a significant decrease in some SCFA and in most volatile 
compounds and can be explained as a consequence of a more complex and diverse microbiota and the activity of LPL, or other enzymes, in cheeses made with no pasteurized milk. Agitation of milk fat, which could improve the accessibility of the lipase to triglycerides, showed significant influence in only a few of the assayed parameters, always interacting with heat treatment factor.

\section{ACKNOWLEDGMENTS}

The authors acknowledge CONICET (Consejo Nacional de Investigaciones Científicas y Técnicas, Argentina) for the doctoral fellowship of M. Ayelén Vélez. The present work was financially supported by grants from UNL (Universidad Nacional del Litoral, Argentina) and ANPCyT (Agencia Nacional de Promoción Científica y Tecnológica, Argentina).

\section{REFERENCES}

ANMAT. 2009. Código Alimentario Argentino. Administración Nacional de Medicamentos, Alimentos y Tecnología Médica, Buenos Aires, Argentina. www.anmat.gov.ar/codigoa/caa1.htm Accessed April 10, 2010.

Atasoy, A., and H. Türkoğlu. 2009. Lypolisis in Urfa cheese produced from raw and pasteurized goats' and cows' milk with mesophilic and thermophilic cultures during ripening. Food Chem. 115:7178.

Barron, L., Y. Redondo, M. Aramburu, P. Gil, F. Pérez-Elortondo, M. Albisu, A. Nájera, M. de Renobales, and E. Fernéndez-García. 2007. Volatile composition and sensory properties of industrially produced Idiazabal cheese. Int. Dairy J. 17:1401-1414.

Battistotti, B., and C. Corradini. 1993. Italian cheese. Pages 221-244 in Cheese: Chemistry, Physics and Microbiology. Vol. 2. P. F. Fox, ed. Chapman \& Hall, London, UK.

Bouton, Y., S. Buchin, G. Duboz, S. Pochet, and E. Beuvier. 2009. Effect of mesophilic lactobacilli and enterococci adjunct cultures on the final characteristics of a microfiltered milk Swiss-type cheese. Food Microbiol. 26:183-191.

Bradley, R., Jr., E. Arnold, D. Barbano, R. Semerad, D. Smith, and B. Vines. 1992. Chemical and physical methods. Pages 433-532 in Standard Methods for the Examination of Dairy Products. R. Marshall, ed. American Public Health Association, Washington, DC.

Buchin, S., V. Delague, G. Duboz, J. Berdague, E. Beuvier, S. Pochet, and R. Grappin. 1998. Influence of pasteurization and fat composition of milk on the volatile compounds and flavor characteristics of a semi-hard cheese. J. Dairy Sci. 81:3097-3108.

Candioti, M., E. Hynes, A. Quiberoni, S. Palma, N. Sabbag, and C. Zalazar. 2002. Reggianito Argentino cheese: Influence of Lactobacillus helveticus strains isolated from natural whey cultures on cheese making and ripening processes. Int. Dairy J. 12:923-931.

Christen, G. L., P. M. Davidson, J. S. McAllister, and L. A. Roth. 1992. Coliform and other indicator bacteria. Pages 247-269 in Standard Methods for the Examination of Dairy Products. R. T. Marshall, ed. American Public Health Association, Washington, DC.

Collins, Y., P. L. H. McSweeney, and M. Wilkinson. 2003. Lipolysis and free fatty acid catabolism in cheese: A review of current knowledge. Int. Dairy J. 13:841-846.

Evers, J. M. 2004a. The milkfat globule membrane-Compositional and structural changes post secretion by the mammary secretory cell. Int. Dairy J. 14:661-674.
Evers, J. M. 2004b. The milkfat globule membrane-Methodologies for measuring milkfat globule (membrane) damage. Int. Dairy J. $14: 747-760$.

Gómez-Ruiz, J., C. Ballesteros, M. González Viñas, L. Cabezas, and I. Martínez-Castro. 2002. Relationships between volatile compounds and odour in Manchego cheese: Comparison between artisanal and industrial cheeses at different ripening times. Lait 82:613-628.

Hickey, D. K., K. N. Kilcawley, T. P. Beresford, and M. G. Wilkinson. 2007. Lipolysis in Cheddar cheese made from raw, thermized, and pasteurized milks. J. Dairy Sci. 90:47-56.

Holland, R., S. Liu, V. L. Crow, M.-L. Delabre, M. Bennett, and G. Norris. 2005. Esterases of lactic acid bacteria and cheese flavor: Milk fat hydrolysis, alcoholysis and esterification. Int. Dairy J. 15:711-718.

Hynes, E. R., L. Aparo, and M. C. Candioti. 2004. Influence of residual milk-clotting enzyme on $\alpha_{\mathrm{s} 1}$ casein hydrolysis during ripening of Reggianito Argentino cheese. J. Dairy Sci. 87:565-573.

IDF. 1982. Standard 4A. Formaggio e formaggio fuso. Determinazione della materia secca. International Dairy Federation, Brussels, Belgium.

IDF. 1983. Standard 22A. Latte scremato, siero di latte e latticello. Determinazione del tenore in grasso. Metodo gravimetrico. International Dairy Federation, Brussels, Belgium.

IDF. 1993. Standard 20B. Determinazione dell'azoto totale del latte. International Dairy Federation, Brussels, Belgium.

IDF. 1995. Standard 50C. Lait et produits laitiers. Guide de l'échantillonnage. International Dairy Federation, Brussels, Belgium.

ISO. 1975. ISO 3433. Cheese-Determination of fat content-Van Gulik method. International Organization for Standardization, Geneva, Switzerland.

Lawrence, R. C., J. Gilles, and L. K. Creamer. 1993. Cheddar cheese and related dry-salted cheese varieties. Pages 1-36 in Cheese: Chemistry, Physics and Microbiology. Vol. 1. P. F. Fox, ed. Chapman \& Hall, London, UK.

Le Quéré, J.-L., and P. Molimard. 2003. Cheese flavor. Pages 330-340 in Encyclopedia of Dairy Science. Vol. 1. H. Roginski, J. Fuquay, and P. Fox, ed. Academic Press, London, UK.

Liu, S., R. Holland, and V. Crow. 2004. Esters and their biosynthesis in fermented dairy products: A review. Int. Dairy J. 14:923-945.

Malacarne, M., A. Summer, P. Franceschi, P. Formaggioni, M. Pecorari, G. Panari, and P. Mariani. 2009. Free fatty acid profile of Parmigiano-Reggiano cheese throughout ripening: Comparison between the inner and outer regions of the wheel. Int. Dairy J. 19:637-641.

Marilley, L., and M. Casey. 2004. Flavors of cheese products: Metabolic pathways, analytical tools and identification of producing strains . Int. J. Food Microbiol. 90:139-159.

McSweeney, P., and M. Sousa. 2000. Biochemical pathways for the production of flavor compounds in cheeses during ripening: A review. Lait 80:293-324.

Molimard, P., and H. E. Spinnler. 1996. Compounds involved in the flavor of surface mold-ripened cheeses: Origins and properties. J. Dairy Sci. 79:169-184

O'Mahony, J., E. Sheehan, C. Delahunty, and P. L. H. McSweeney. 2006. Lipolysis and sensory characteristics of Cheddar cheeses ripened using different temperature-time treatments. Lait 86:5972 .

Ortigosa, M., P. Torre, and J. M. Izco. 2001. Effect of pasteurization of ewe's milk and use of a native starter culture on the volatile components and sensory characteristics of Roncal cheese. J. Dairy Sci. $84: 1320-1330$.

Perotti, M. C., S. Bernal, C. A. Meinardi, and C. A. Zalazar. 2005. Free fatty acid profiles of Reggianito cheese produced with different starters. Int. Dairy J. 15:1150-1155.

Pinna, G., A. Pirisi, G. Piredda, M. Addis, and R. Di Salvo. 1999. Effetto della termizzazione del latte sul formaggio DOP Fiore Sardo: 2. Andamento della lipolisi nel corso della maturazione. Sci. e Tec. Latt. Cas. 50:366-377. 
Qian, M., and G. Reineccius. 2003. Static headspace and aroma extract dilution analysis of Parmigiano Reggiano cheese. J. Food Sci. 68:794-798.

Shakeel-Ur-Rehman, P. L. H. McSweeney, J. M. Banks, E. Y. Brechany, D. D. Muir, and P. F. Fox. 2000. Ripening of cheddar cheese made from blends of raw and pasteurised milk. Int. Dairy J. 10:33-44.

Skeie, S., and Y. Ardö. 2000. Influence from raw milk flora on cheese ripening studied by different treatments of milk to model cheese. Lebensm. Wiss. u. Technol. 33:499-505.

Urbach, G. 1995. Contribution of lactic acid bacteria to flavor compounds formation in dairy products. Int. Dairy J. 5:877-903.

Voigt, D., F. Chevalier, M. Qian, and A. Kelly. 2010. Effect of highpressure treatment on microbiology, proteolysis, lipolysis and lev- els of flavor compounds in mature blue-veined cheese. Innov. Food Sci. Emerg. Technol. 11:68-77.

Walstra, P., T. J. Geurts, A. Noomen, A. Jellema, and M. A. van Boekel. 1999. Colloidal particles of milk. Pages 107-149 in Dairy Technology: Principles of Milk Properties and Processes. Marcel Dekker Inc., New York, NY.

Werner, H., E. Nielsen, Y. Ardö, A. Rage, and V. Antila. 1993. North European varieties of cheese. Pages 245-262 in Cheese: Chemistry Physics and Microbiology. Vol. 2. P. F. Fox, ed. Chapman \& Hall, London, UK.

Zannoni, M., M. Nanni, and R. Mora. 1984. Influenza di diverse modalita di affioramento sulle caratteristiche casearie del latte e sul formaggio Parmigiano-Reggiano ottenuto. Sci. Tec. Latt. Cas. $35: 541-556$. 